\title{
Analysis of Research Method, Results and Regulations Regarding the Exhaust Emissions from Two-Wheeled Vehicles under Actual Operating Conditions
}

\author{
Natalia Szymlet ${ }^{1 *}$, Piotr Lijewski ${ }^{1}$, Barbara Sokolnicka ${ }^{1}$, Maciej Siedlecki ${ }^{1}$, \\ Andrzej Domowicz ${ }^{1}$ \\ 1 Poznan University of Technology, Faculty of Transport Engineering, Institute of Combustion Engines and \\ Transport, ul. Piotrowo 3, PL 60-965 Poznań, Poland, \\ * Corresponding author's e-mail: natalia.r.szymlet@doctorate.put.poznan.pl
}

\begin{abstract}
The subject of this article was the analysis of the current state of legislation regarding the exhaust emissions from two-wheeled vehicles. The regulations and emission limits were analyzed and compared for different areas of the world. Moreover, the review of the legal provisions includes an individual approach to specific categories of two-wheeled vehicles. The study also describes the research and exhaust emission measurement methods from mopeds and motorcycles both under laboratory conditions and in actual operation. The methods were evaluated in the aspect of future emission requirements and trends. In addition, the results of emissivity measurements under actual operating conditions obtained in the Poznań agglomeration with the use of motorcycle units were discussed and analyzed. The values of road emissions of all toxic compounds limited by legislators were compared with emission standards.
\end{abstract}

Keywords: air pollution, two-wheeled vehicles, exhaust emission, RDE methodology, PEMS.

\section{INTRODUCTION}

In 1942, the smog phenomenon was first identified in California. A decade later, it was discovered that it was formed as a result of the emissions of nitrogen oxides and unburned hydrocarbons, to which transport also contributed. In 1966, a law was introduced there to control the car emissions. Over the next few years, the Environmental Protection Agency was established, which introduced the first limits. The Agency's activities led to the spread of catalytic converters, sensors measuring the oxygen content and the introduction of unleaded gasoline. In Europe, two-wheelers belong to the L category vehicles. The first provisions regarding their emission were brought about in 1972 by Directive 72/306/EEC [European Union 2005] and Regulation 24, with the provisions regarding two-wheelers only contained in the regulations, while the Directive deals with four-wheeled vehicles. Currently, the European Union regulates the emission of carbon monoxide, hydrocarbons and nitrogen oxides for two-wheelers. The current European standard for two-wheelers is the EURO 4 norm. In the twowheelers with a displacement of over $125 \mathrm{~cm}^{3}$, the ABS system has become mandatory and an integrated vehicle braking systems for the engines with smaller displacement. Another change brought by this standard is the abandonment of carburetor systems in favor of electronic carburetors and injectors. Catalytic systems are equipped with lambda probes. The perceptible advantage of the current legislation for the vehicle user is the reduction of the fuel consumption and improvement in the level of reliability of two-wheelers with smaller displacement engines, due to the replacement of some mechanical systems, often requiring adjustment, with electronic ones. The upcoming change on the European vehicle 
market is the EURO 5 norm, which is expected to enter into force in 2020. It not only provides a reduction in the maximum permitted emission of toxic compounds, but also an increase in the number of diagnostic points in the engine, especially in the exhaust aftertreatment system. In recent years, there has been a growing emphasis on the research conducted under actual traffic conditions. Higher emissions of nitrogen oxides under actual traffic conditions was found, in addition to frequent significant discrepancy in fuel consumption between the information contained in the vehicle technical data sheet and the values observed during everyday operation, which was already pointed out by scientists and vehicle users themselves [Hiesmayr et al. 2017; Kumar et al. 2011; Tong, Hung and Cheung 2000].

\section{LEGAL ASPECTS OF TWO- WHEELED VEHICLE EMISSIONS}

As a result of Directive 2007/46/EC [European Union 2007], an L type approval category was established, which included the bikes equipped with an engine, two- and three-wheel mopeds, motorcycles, motorcycles with side-car, three-wheeled vehicles, microcars, four-wheel off-road vehicles and four-wheeled vehicles. Separate emission norms are set by the European Union, the United States and California, as well as Brazil, Chile, China, India, Indonesia, Japan, Singapore, South Korea, Thailand and Vietnam. Some of these countries model their norms on the EURO standards, introducing them a few years after their introduction in Europe. The current standard on the European market for two-wheelers is the EURO 4 standard, while the EURO 5 standard will come into force in 2020 (Table 1).
The American motorbike emission norms have been setting maximum emission values since 1980: HC $5 \mathrm{~g} / \mathrm{km}, \mathrm{CO} 12 \mathrm{~g} / \mathrm{km}$. The data was collected using the FTP-75 test. For the vehicles manufactured up to and including the year 2005, no exhaust fumes emission norms have been set. The california norms (since 2004) and federal norms (since 2006), specify the average hydrocarbon emissions for a given manufacturer. Unlike European norms, they do not distinguish between different types of fuel.

Currently, the toxic exhaust emissions of two-wheeled vehicles are tested using a chassis dynamometer and adopted type approval tests. Each test determines the masses of carbon monoxide, hydrocarbons, nitrogen oxide, carbon dioxide and fuel consumed during the measurement cycle. The dust mass is determined for certain categories. The ECE R40 (European Emission Test Cycle) lasts 1170 seconds and consists of six basic urban cycles (Fig. 1). Each of those cycles consists of fifteen phases reflecting the aspects of actual driving conditions. The ECE R47 test cycle lasts 896 seconds and consists of eight basic cycles (Fig. 2), which must be carried out without interruption, and the measurement is made throughout the entire driving cycle, from the moment the engine is started.

Each of the cycles consists of seven phases, reflecting the driving conditions. For the vehicles of the L1e-A and L1e-B categories with a maximum expected speed of $25 \mathrm{~km} / \mathrm{h}$, the cut-off speed chart applies. In turn. the WMTC (World Motorcycle Test Cycle) test cycle lasts $1800 \mathrm{sec}-$ onds and consists of three parts (Fig. 3). As with ECE R40 and ECE R47 cycles, they should be performed without interruption. The WMTC test will apply to all two-wheeled vehicles with the entry into force of the EURO 5 standard in 2020.

Table 1. Limit values for toxic compounds emission in the EURO 5 norm [Delphi 2017]

\begin{tabular}{|c|c|c|c|c|c|c|c|c|}
\hline \multicolumn{9}{|c|}{ EURO 5 STEP } \\
\hline \multirow{3}{*}{$\begin{array}{l}\text { Vehicle } \\
\text { Category }\end{array}$} & \multirow{3}{*}{$\begin{array}{l}\text { Vehicle } \\
\text { Category } \\
\text { Name }\end{array}$} & \multirow{3}{*}{$\begin{array}{l}\text { Propulsion } \\
\text { Class }\end{array}$} & \multicolumn{5}{|c|}{ Mass of $[\mathrm{mg} / \mathrm{km}]$} & \multirow{3}{*}{$\begin{array}{c}\text { Test } \\
\text { Cycle }\end{array}$} \\
\hline & & & $\mathrm{CO}$ & THC & NHMC & $\mathrm{NO}_{\mathrm{x}}$ & PM & \\
\hline & & & $\mathrm{L}_{1}$ & $L_{2 A}$ & $\mathrm{~L}_{2 \mathrm{~B}}$ & $\mathrm{~L}_{3}$ & $\mathrm{~L}_{4}$ & \\
\hline L1e-A & Powered cycle & $\begin{array}{l}\mathrm{Pl} / \mathrm{Cl} / \\
\text { Hybrid }\end{array}$ & 500 & 100 & 68 & 60 & 4,5 & WMTC \\
\hline \multirow{2}{*}{ L1e-B-L7e } & \multirow{2}{*}{$\begin{array}{l}\text { All other } \\
\text { L-category } \\
\text { vehicles }\end{array}$} & $\begin{array}{l}\text { Pl/PI/ } \\
\text { Hybrid }\end{array}$ & 1000 & 100 & 68 & 60 & 4,5 & WMTC \\
\hline & & $\begin{array}{l}\mathrm{Cl} / \mathrm{Cl} / \\
\text { Hybrid }\end{array}$ & 500 & 100 & 68 & 90 & 4,5 & WMTC \\
\hline
\end{tabular}



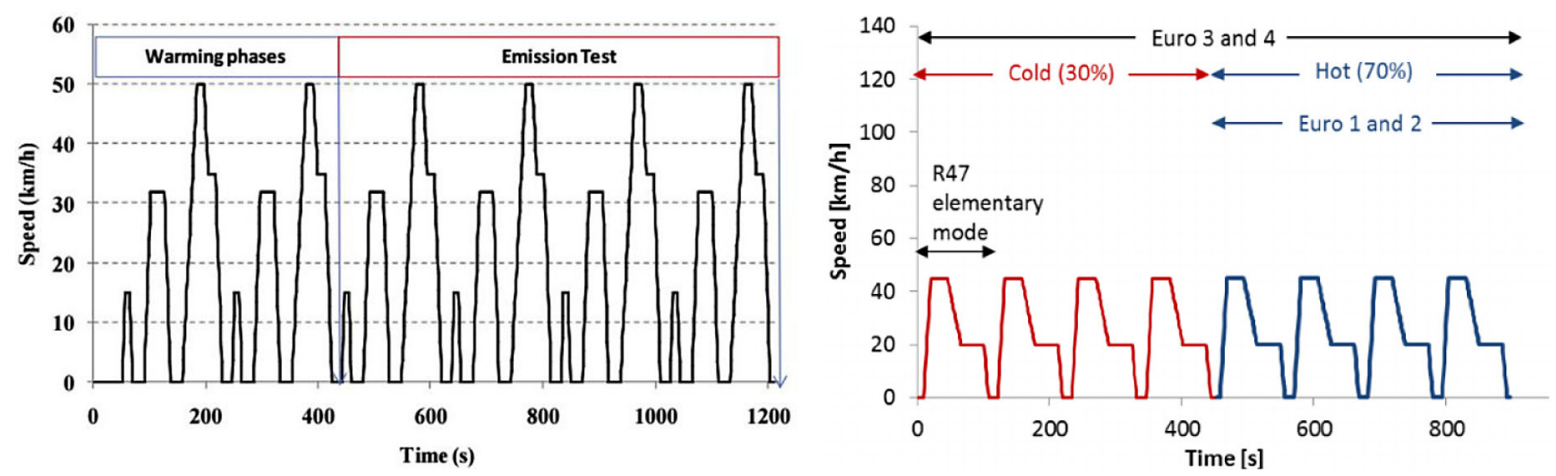

Fig. 1. Characteristics of tests a) ECE R40 [Khanh, Han and Vinh 2018] b) ECE R47

[Giechaskiel, Zardini and Martini 2015]

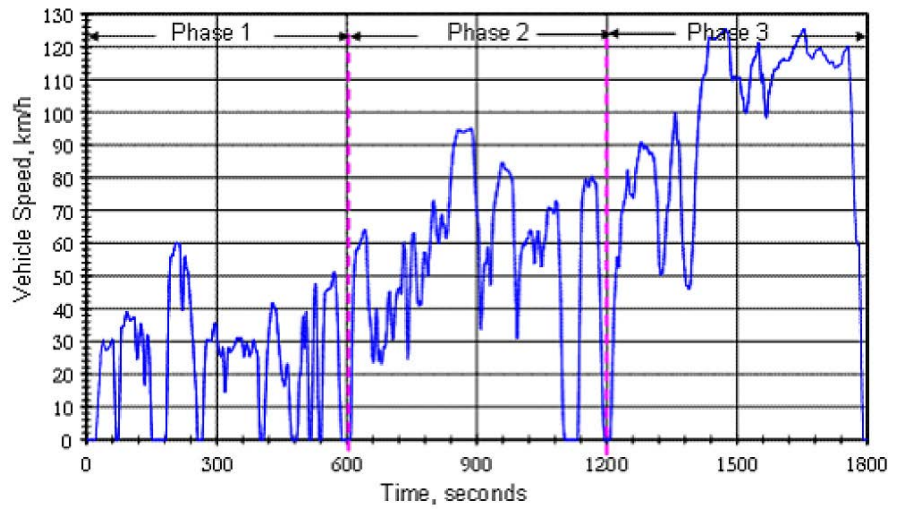

Fig. 2. Characteristics of a WMTC test [asphaltandrubber.com 2019]

\section{RDE TESTS - OVERVIEW}

It was noticed that results of the test conducted under laboratory conditions deviate significantly from the test results under actual traffic conditions, especially in terms of load variability, which affects the work of exhaust aftertreatment systems and the exhaust emissions of harmful components, especially carbon monoxide. [Fuć et al. 2004].

From September 1, 2017, new car models are subject to RDE (Real Driving Emissions) and WLTP (World Harmonized Light Vehicle Test Procedure) tests. Non-compliance to the limit values determined on the basis of valid type approval tests and values obtained under actual operating conditions was also found for other road and off-road vehicles, including motorcycles and mopeds. This incompatibility has been well documented and is the subject of this article.

In the RDE test, supplementing laboratory tests, the vehicle moves under actual operating conditions, according to randomly selected parameters [Pielecha 2017]. It provides complete and very accurate monitoring of pollutants emitted by engines in real time, along with the related engine, vehicle and environment parameters. The measurement is carried out using portable emission measurement systems (PEMS) that are mounted on the vehicle (Fig. 3).

In the case of passenger cars, it lasts between 90 and 120 minutes and consists of three sections: urban (speed of up to $60 \mathrm{~km} / \mathrm{h}, 34 \%$ of distance), rural (speed $60-90 \mathrm{~km} / \mathrm{h}, 33 \%$ of distance) and highway (speed over $90 \mathrm{~km} / \mathrm{h}, 33 \%$ of the distance), with an accuracy of \pm 10 percent points for the distances, with at least $29 \%$ being an urban part. The maximum duration of one-time stop of the vehicle is $180 \mathrm{~s}$. The ambient temperature should be between $0^{\circ} \mathrm{C}$ and $30^{\circ} \mathrm{C}$ (the extended range lowers the minimum to $-7^{\circ} \mathrm{C}$, and increases the maximum to $35^{\circ} \mathrm{C}$ ). Topographic altitude should be at most $700 \mathrm{~m}$ a.s.l. (extended range increases that to: $700<\mathrm{h} \leq 1300 \mathrm{~m}$ a.s.l.), and a total height increase of less than $1200 \mathrm{~m} / 100 \mathrm{~km}$. The RDE tests are carried out on working days on paved roads and streets. The measuring equipment should be installed with particular focus on 


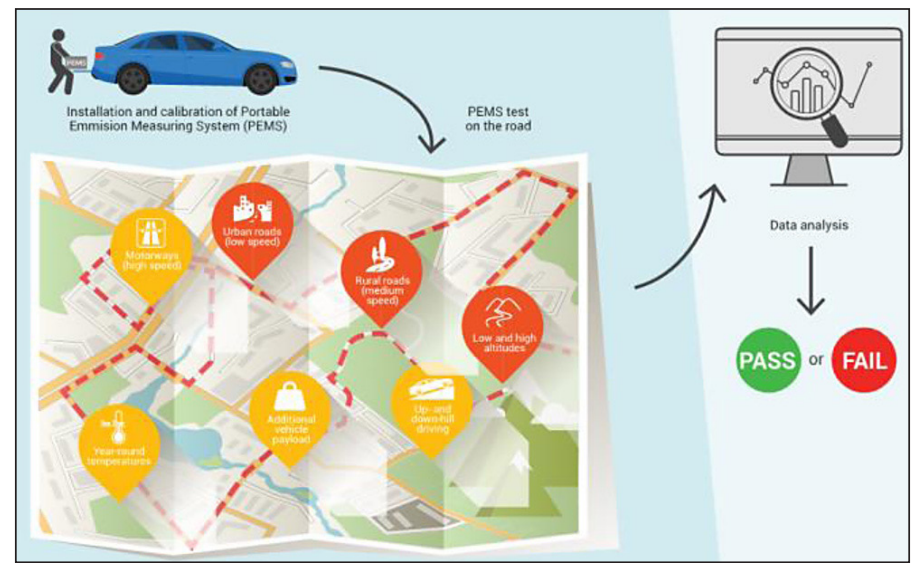

Fig. 3. RDE testing method [caremissiontestingfacts.eu 2019]

causing the smallest possible impact on the exhaust emissions of the vehicle and its operation, as well as on the smallest possible impact on the weight and aerodynamics of the vehicle itself.

The Institute of Internal Combustion Engines and Transport at the Poznań University of Technology specializes in testing the toxic exhaust emissions under actual operating conditions from vehicles of various categories, which has been described, among others in [Merkisz et al. 2014; Merkisz et al. 2012].

\section{RESEARCH METHOD}

\section{Research objects}

For the emissivity conducted tests under actual operating conditions, two two-wheeled vehicles belonging to the category L3e were used. The first one was a motorcycle, equipped with a four-stroke engine with a displacement of $125 \mathrm{~cm}^{3}$ and a power of $9 \mathrm{~kW}$ (Fig. 4a). In addition, the vehicle was equipped with a three-way catalytic converter and a start-stop system (the start-stop system was inactive during the performed tests). Its technical data is presented in Table 2. The second research object represented a four-stroke motorcycle with a displacement of $847 \mathrm{~cm}^{3}$ and a power of $84.5 \mathrm{~kW}$ (Fig. 4b). Its wider specification is presented in Table 3. Both vehicles were manufactured in 2017, and so they were approved with the current EURO 4 standard. Before the tests, the vehicles were checked for possible defects, and both drives were performed by the same driver to avoid the impact change of driving style on the final results.

\section{TEST ROUTE}

The tests under actual operating conditions were carried out in the city center of Poznań. It was selected based on the specific road conditions, containing a sufficiently large number of intersections, traffic lights and vehicle speed limits (particularly important in the case the first vehicle test drive). The route was $7.1 \mathrm{~km}$ long, and its
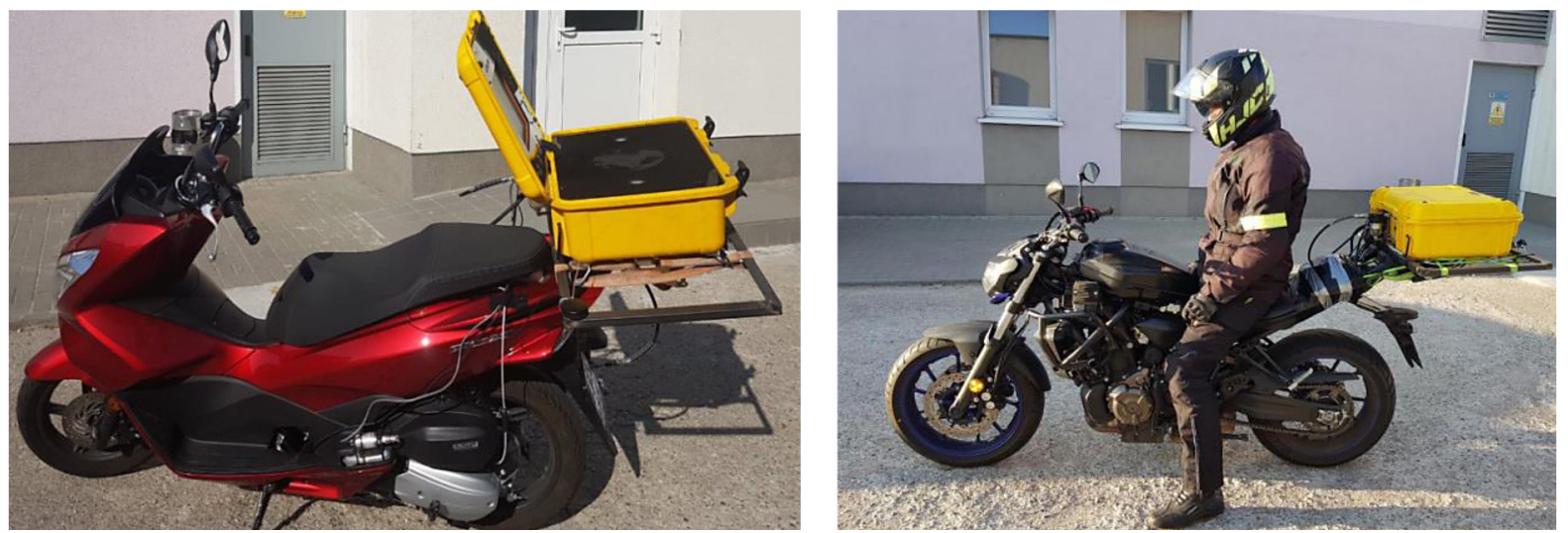

Fig. 4. Tested vehicles with the measuring equipment installed 
Table 2. Test vehicle technical data

\begin{tabular}{|l|c|}
\hline Engine type & 4 stroke \\
\hline $\begin{array}{l}\text { Number and arrangement of } \\
\text { cylinders, number of valves }\end{array}$ & $\begin{array}{c}\text { single-cylinder, } \\
2 \text { valves }\end{array}$ \\
\hline Displacement & $125 \mathrm{~cm}^{3}$ \\
\hline Bore/stroke & $52.4 \mathrm{~mm} / 57.9 \mathrm{~mm}$ \\
\hline Maximum power & $9.0 \mathrm{~kW} / 8500 \mathrm{rpm}$ \\
\hline Maximum torque & $11.8 \mathrm{Nm} / 5000 \mathrm{rpm}$ \\
\hline Cooling & liquid \\
\hline
\end{tabular}

beginning took place at the Poznan University of Technology at the laboratory of the Institute of Internal Combustion Engines and Transport, which greatly facilitated the research process. Both tests were carried out in the afternoon so that the driving conditions were as similar as possible. The test route (Fig. 5) was created on the basis of the data from the GPS system and the GPSvisualizer program.

\section{MEASURING EQUIPMENT}

The exhaust emission tests from twowheeled vehicles under actual operating conditions were carried out in both cases using the
Table 3. Test vehicle technical data

\begin{tabular}{|l|c|}
\hline Engine type & 4-stroke, DOHC \\
\hline $\begin{array}{l}\text { Number and arrangement of } \\
\text { cylinders, number of valves }\end{array}$ & $\begin{array}{c}\text { 3-cylinder, } \\
4 \text { valves }\end{array}$ \\
\hline Displacement & $847 \mathrm{~cm}^{3}$ \\
\hline Bore/stroke & $78 \mathrm{~mm} / 59.1 \mathrm{~mm}$ \\
\hline Maximum power & $84.6 \mathrm{~kW} / 10000 \mathrm{rpm}$ \\
\hline Maximum torque & $87.5 \mathrm{Nm} / 8500 \mathrm{rpm}$ \\
\hline Cooling & liquid \\
\hline
\end{tabular}

same measuring apparatus so that the results were as comparable as possible. The AXION $\mathrm{R} / \mathrm{S}+$ device, belonging to the PEMS (Portable Emission Measurement System) group, was used for this research. The apparatus measures the emission of harmful and toxic compounds, both gaseous: hydrocarbons (HC), carbon monoxide $(\mathrm{CO})$, carbon dioxide $\left(\mathrm{CO}_{2}\right)$, nitrogen oxide (NO) as well as solid particles. The specification of the device is shown in Table 4, while the apparatus itself is shown in Figure 6. Electrochemical analyzers are used to determine the emissions of $\mathrm{NO}$ and $\mathrm{O}_{2}$. The concentrations of hydrocarbons, carbon monoxide, and carbon dioxide are measured using a non-dispersion

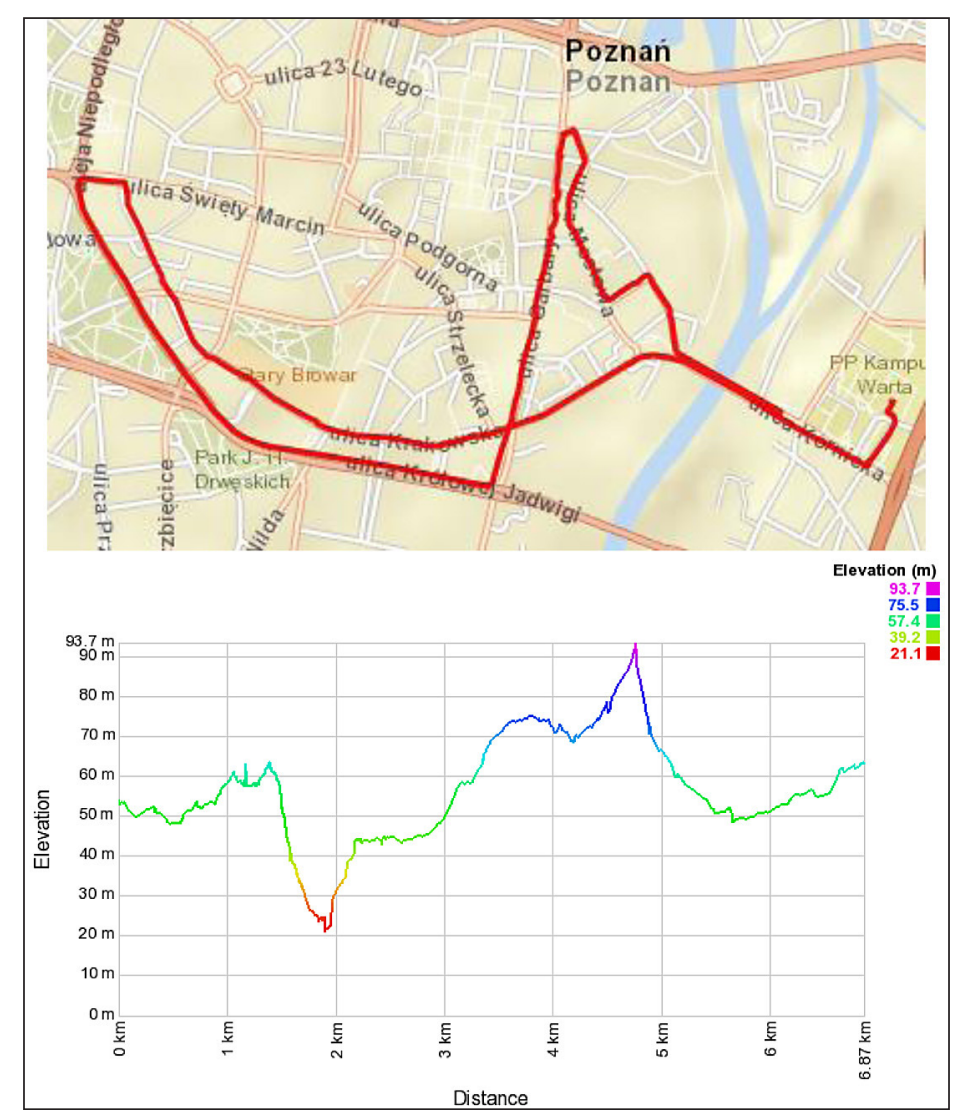

Fig. 5. The test route [gpsvisualizer.com 2019] 
Table 4. The AxionR/S+ device operating parameters [globalmrv.com 2019]

\begin{tabular}{|c|c|c|c|c|}
\hline Gas & Mesaurement range & Accuracy & Resolution & Type of mesaurement \\
\hline $\mathrm{HC}$ & $0-4000 \mathrm{ppm}$ & $\pm 8 \mathrm{ppm}$ abs. or $\pm 3 \%$ rel. & $1 \mathrm{ppm}$ & NDIR \\
\hline $\mathrm{CO}$ & $0-10 \%$ & $\pm 0.02 \%$ abs. or $\pm 3 \% \mathrm{rel}$. & $0.001 \mathrm{vol} . \%$ & NDIR \\
\hline $\mathrm{CO}_{2}$ & $0-16 \%$ & $\pm 0.3 \%$ abs. or $\pm 4 \%$ rel. & $0.01 \mathrm{vol} . \%$ & NDIR \\
\hline $\mathrm{NO}$ & $0-4000 \mathrm{ppm}$ & $\pm 25 \mathrm{ppm}$ abs. or $\pm 3 \%$ rel. & $1 \mathrm{ppm}$ & E-chem \\
\hline $\mathrm{O}_{2}$ & $0-25 \%$ & $\pm 0.1 \% \mathrm{ppm}$ abs. or $\pm 3 \%$ rel. & $0.01 \mathrm{vol} . \%$ & E-chem \\
\hline $\mathrm{PM}$ & $0 \mathrm{mg} / \mathrm{m}^{3}$ to $300 \mathrm{mg} / \mathrm{m}^{3}$ & $\pm 2 \%$ & $0.01 \mathrm{mg} / \mathrm{m}^{3}$ & Laser Scatter \\
\hline
\end{tabular}

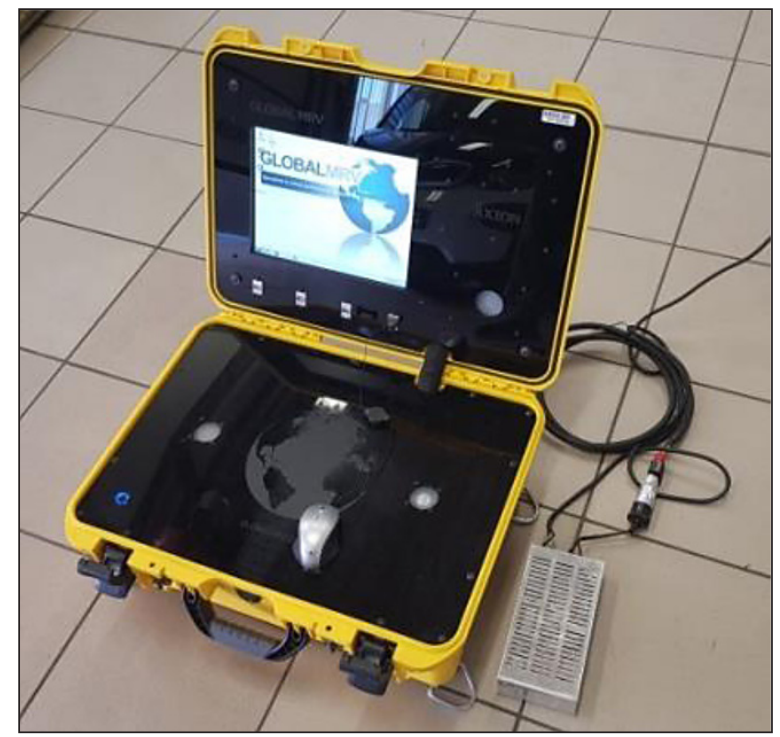

Fig. 6. The measuring equipment used

infrared analyzer - NDIR (Nondispersive Infrared Sensor). In turn, a method based on Laser Scatter is used for measuring the PM emission.

Moreover, the device is equipped with a weather station, a GPS and a module for recording the data from the OBD (On-Board Diagnostic) vehicle diagnostic system. The data measurement and acquisition was carried out at a frequency of $1 \mathrm{~Hz}$. On the basis of the recorded data, corrections of the obtained results are made, and then the road/specific emission of the tested exhaust gases was calculated.

The device is one of the most modern measuring instruments, housing analyzers for measuring both gaseous and solid compounds in a housing weighing only $18 \mathrm{~kg}$. Low weight and dimensions mean that it can be used to test the emission of all toxic compounds limited by standards from twowheeled vehicles under actual operating conditions. In addition, the device also measures the particulate matter emissions, the limit on which is expected to enter into effect in 2020 along with the introduction of the EURO 5 norm.

\section{ANALYSIS AND RESULTS}

The tests carried out under actual operating conditions allowed plotting comparative characteristics of vehicle speed curves and the exhaust emission intensity in real time during the measurements. For both drives, the highest recorded speed is about $70 \mathrm{~km} / \mathrm{h}$, which probably resulted from a temporary change in the terrain, i.e. "coasting". Significant differences in the emission values of all toxic compounds are noticeable, which is undoubtedly related to the different technical parameters of the engines of the tested vehicles. This fact confirms that for typical urban conditions (numerous stops, speeds of up to $50 \mathrm{~km} / \mathrm{h}$ ) smaller motorcycles with smaller engine displacement will be more environmentally favorable, such as with engines up to $250 \mathrm{~cm}^{3}$ and mopeds (Fig. $7-9$ ). Only in the case of nitrogen oxides emissions, the opposite is the case, which is associated with higher loads in the engines with lower maximum power (Fig. 10). In the case of a motorcycle with a larger engine, the urban drive cycle should be treated only as part of the whole research test, while for mopeds and small motorcycles (colloquially called scooters) this cycle by itself is sufficient to develop the RDE methodology.

Moreover, the measurement data obtained while driving in urban traffic allowed plotting the characteristics of the time density for each of the tested two-wheeled vehicles; thus, a graphical representation of the share of operating time in individual speed and acceleration intervals was prepared. The relations obtained showed that both vehicles most often worked in the interval of $0 \mathrm{~km} / \mathrm{h}$ speed and acceleration in the range $\left(-0.5-0 \mathrm{~m} / \mathrm{s}^{2}\right)$, i.e. at idle. The operating time share in this interval was $34 \%$ and $32 \%$, for a motorcycle with a displacement of $125 \mathrm{~cm}^{3}$ and $900 \mathrm{~cm}^{3}$, respectively (Fig. 11). This is related to the characteristics of urban traffic, which includes the phenomenon of road congestion or frequent intersections with traffic lights. 


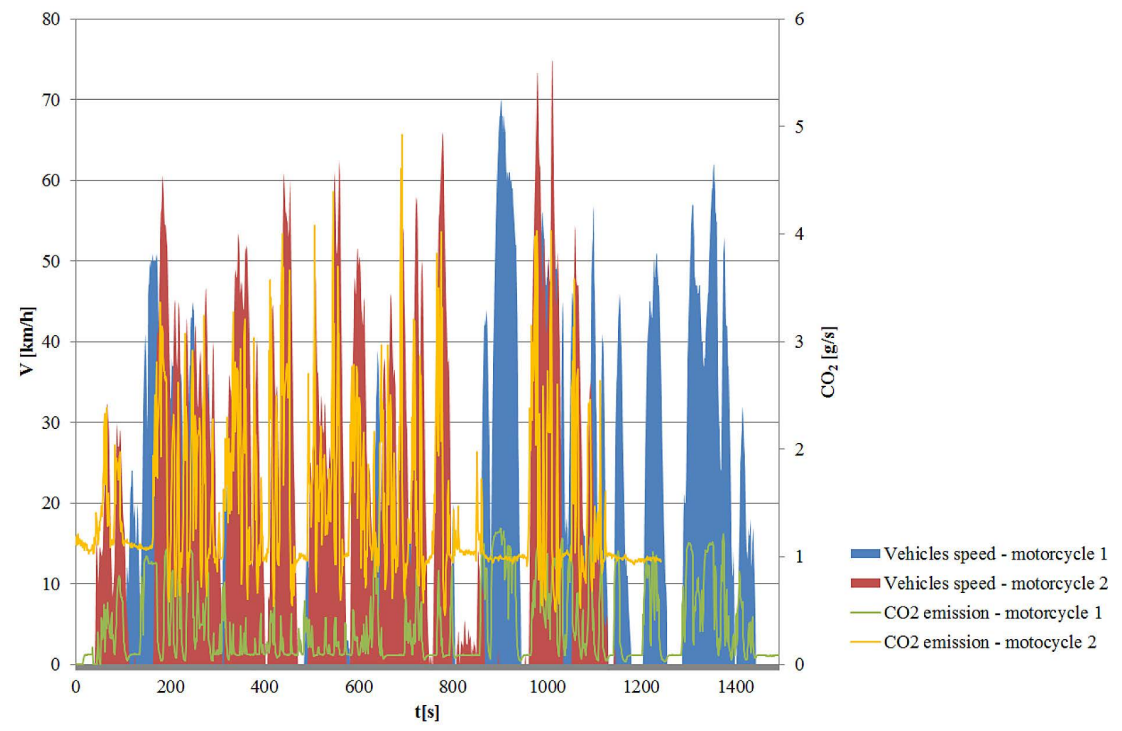

Fig. 7. The $\mathrm{CO}_{2}$ emission characteristics and vehicle speed presented in time

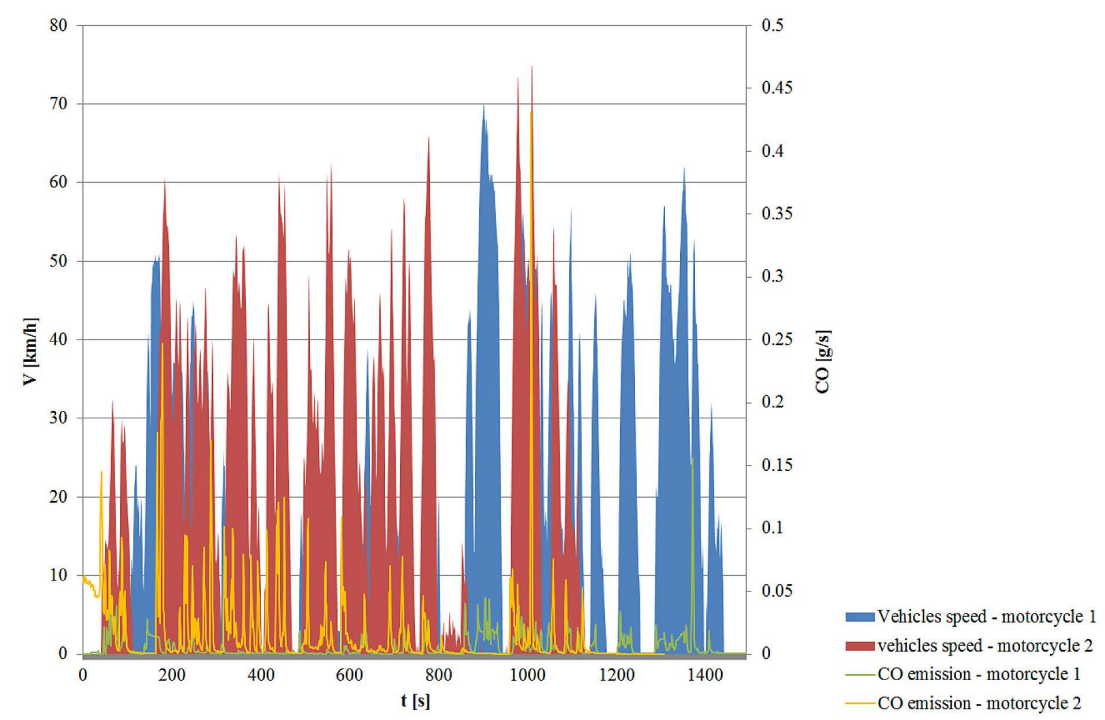

Fig. 8. The $\mathrm{CO}$ emission characteristics and vehicle speed presented in time

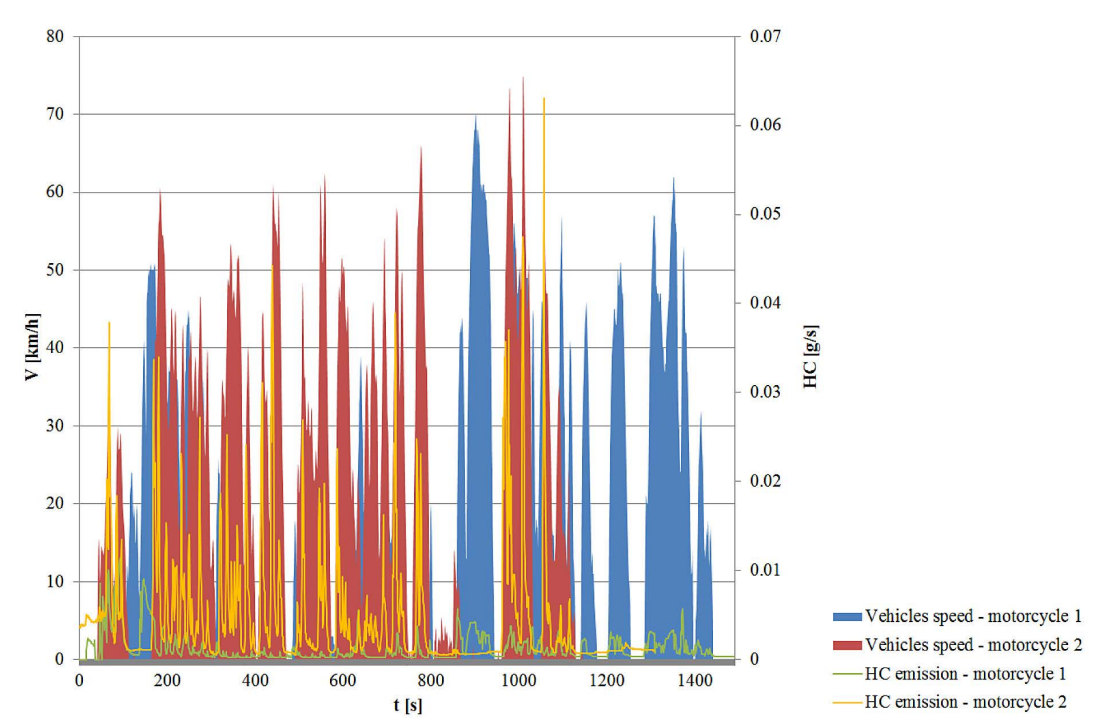

Fig. 9. The $\mathrm{HC}$ emission characteristics and vehicle speed presented in time 


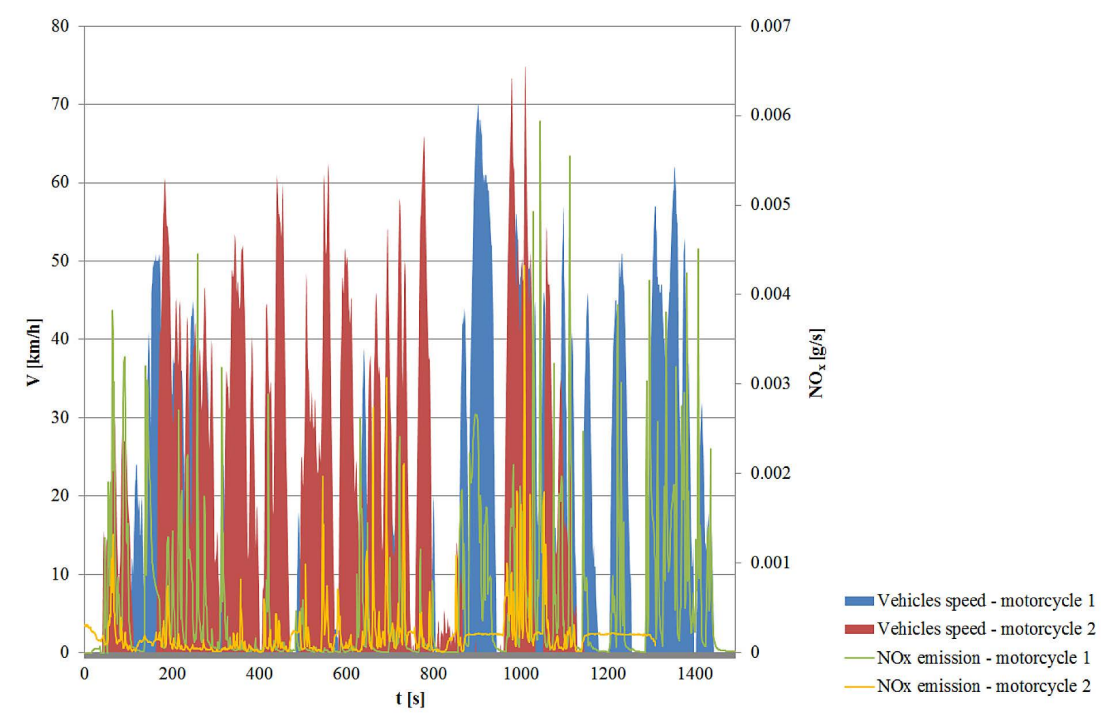

Fig. 10. The $\mathrm{NO}_{\mathrm{x}}$ emission characteristics and vehicle speed presented in time
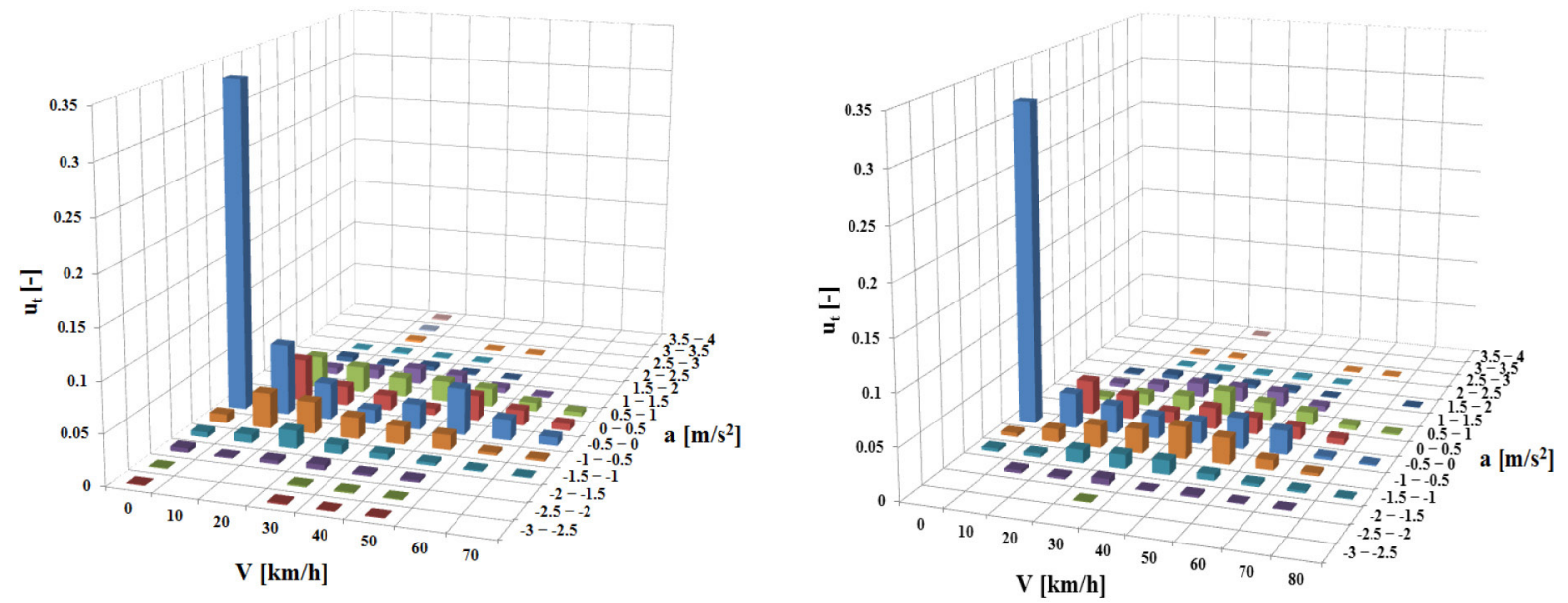

Fig. 11. Time density characteristics of a two-wheeled vehicle a) motorcycle with a displacement of $125 \mathrm{~cm}^{3}$ b) motorcycle with a displacement of $900 \mathrm{~cm}^{3}$

In the case of the smaller motorcycle, a significant share of operating time was also observed for the speed interval $(0-20 \mathrm{~km} / \mathrm{h})$ and acceleration $\left(-1-0.5 \mathrm{~m} / \mathrm{s}^{2}\right)$ which in total amounted to $21 \%$. This is confirmed by the average vehicle speed, which was $17.4 \mathrm{~km} / \mathrm{h}$. While analyzing the density characteristics for the larger motorcycle and the same speed and acceleration intervals, the share of operating time was $14 \%$ of the entire test duration. In addition, both vehicle engines also worked for a long time in the interval of high vehicle speeds between $30-50 \mathrm{~km} / \mathrm{h}$ and low accelerations in the interval $\left(-1-1 \mathrm{~m} / \mathrm{s}^{2}\right)$, in which the total operating time share in both cases was $19 \%$.

The recorded measurement data obtained during the tests enabled the analysis of emission ratios of the motorcycles depending on their operational parameters, which included all toxic compounds limited by the EURO 4 norm (carbon monoxide, hydrocarbons, nitrogen oxides) as well as the non-limited carbon dioxide.

The carbon dioxide exhaust emission values wererecordedintheentirespeedrangeoftestvehicles (Fig. 12). For the lower power motorcycle, the highest value was recorded for the interval of high accelerations of $\left(1-1.5 \mathrm{~m} / \mathrm{s}^{2}\right)$ and speed $(50-60 \mathrm{~km} / \mathrm{h})$, and it amounted to $1.986 \mathrm{~g} / \mathrm{s}$. In the case of the second test vehicle, the local maximum was also recorded in the data interval of high speeds in the range $(60-70 \mathrm{~km} / \mathrm{h})$ and average accelerations of $\left(0.5-1 \mathrm{~m} / \mathrm{s}^{2}\right)$, and its value was $3.83 \mathrm{~g} / \mathrm{s}$. The mean emission values of this compound obtained during the tests were $0.23 \mathrm{~g} / \mathrm{s}$ for the lower power motorcycle and $1.4 \mathrm{~g} / \mathrm{s}$ for the higher power vehicle. 

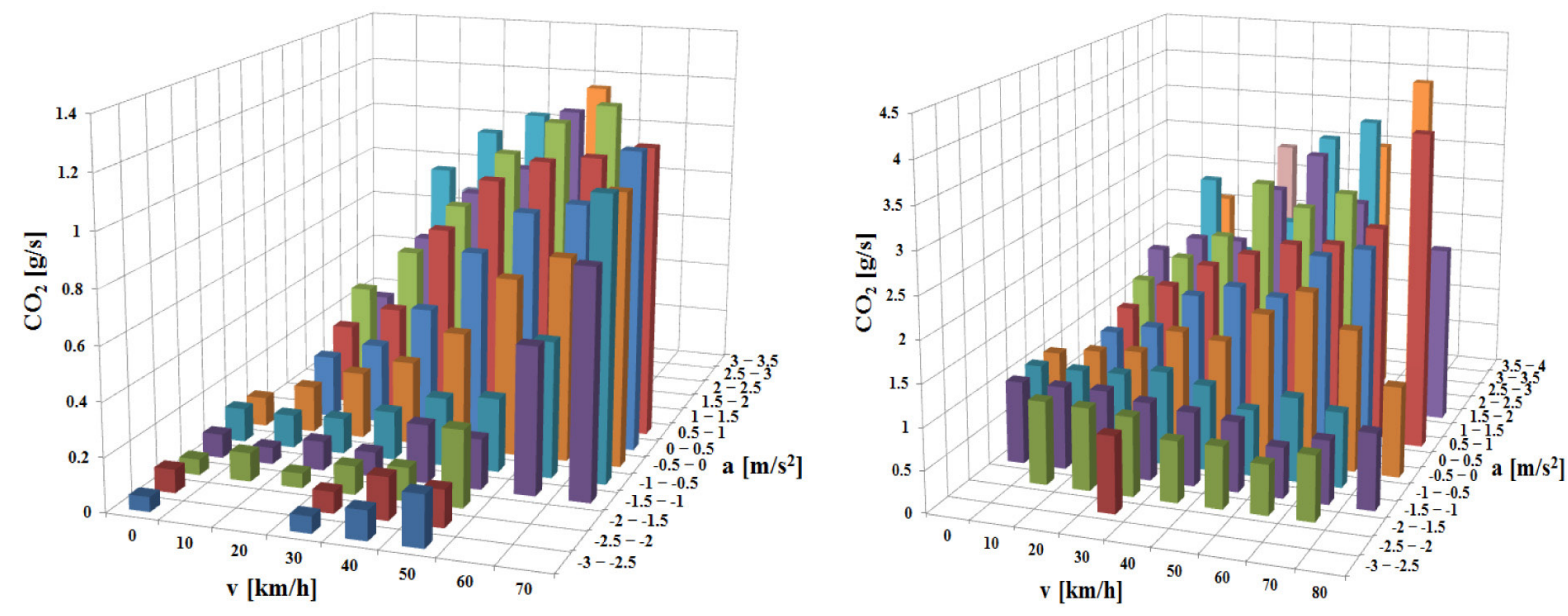

Fig. 12. $\mathrm{CO}_{2}$ exhaust emission in speed and acceleration intervals a) motorcycle with engine displacement of $125 \mathrm{~cm}^{3}$ b) motorcycle with engine displacement of $900 \mathrm{~cm}^{3}$

The analysis of characteristics pertaining to the carbon monoxide exhaust emission intensity reveals that while its values were recorded for the entire range of engine rotational speeds, its distribution was not as uniform as in the case of carbon dioxide emissions (Fig. 13). Clear peaks in values can be observed, which in the case of the first motorcycle were found in the interval of high vehicle speeds in the range $(40-50 \mathrm{~km} / \mathrm{h})$ and accelerations in the interval of $\left(1.5-2 \mathrm{~m} / \mathrm{s}^{2}\right)$, and amounted to $0.146 \mathrm{~g} / \mathrm{s}$. For the other motorcycle with a displacement of $900 \mathrm{~cm}^{3}$, the highest carbon monoxide emissions were recorded at high vehicle speeds and accelerations, in the intervals $(60-70 \mathrm{~km} / \mathrm{h})$ and $\left(2.5-3 \mathrm{~m} / \mathrm{s}^{2}\right)$. As mentioned previously, such high vehicle speed values were the result of the temporary changes in the terrain elevation. The conditions for local maxima (high speeds, high doses of fuel supplied) are a favorable environment for this compound to form, which is caused by local and global oxygen deficiencies. These emission values are also affected by locally high temperatures causing thermal dissociation of carbon dioxide. The mean values of carbon monoxide emissions were $0.0052 \mathrm{~g} / \mathrm{s}$ and $0.015 \mathrm{~g} / \mathrm{s}$, for the two vehicles, respectively.

The hydrocarbon exhaust emission intensity values, same as in the case of previous harmful compounds, were also dependent on the vehicle operating parameters (Fig. 14). The highest emission values of this compound were recorded for high vehicle speeds and accelerations in the intervals $(40-50 \mathrm{~km} / \mathrm{h})$ and $\left(1.5-2 \mathrm{~m} / \mathrm{s}^{2}\right)$ for a motorcycle with engine displacement of $125 \mathrm{~cm}^{3}$, and its value was $0.005 \mathrm{~g} / \mathrm{s}$. For the more powerful twowheeled vehicle, this value amounted to $0.047 \mathrm{~g} / \mathrm{s}$ and was found in two intervals of high speeds and accelerations which were $(60-70 \mathrm{~km} / \mathrm{h})$
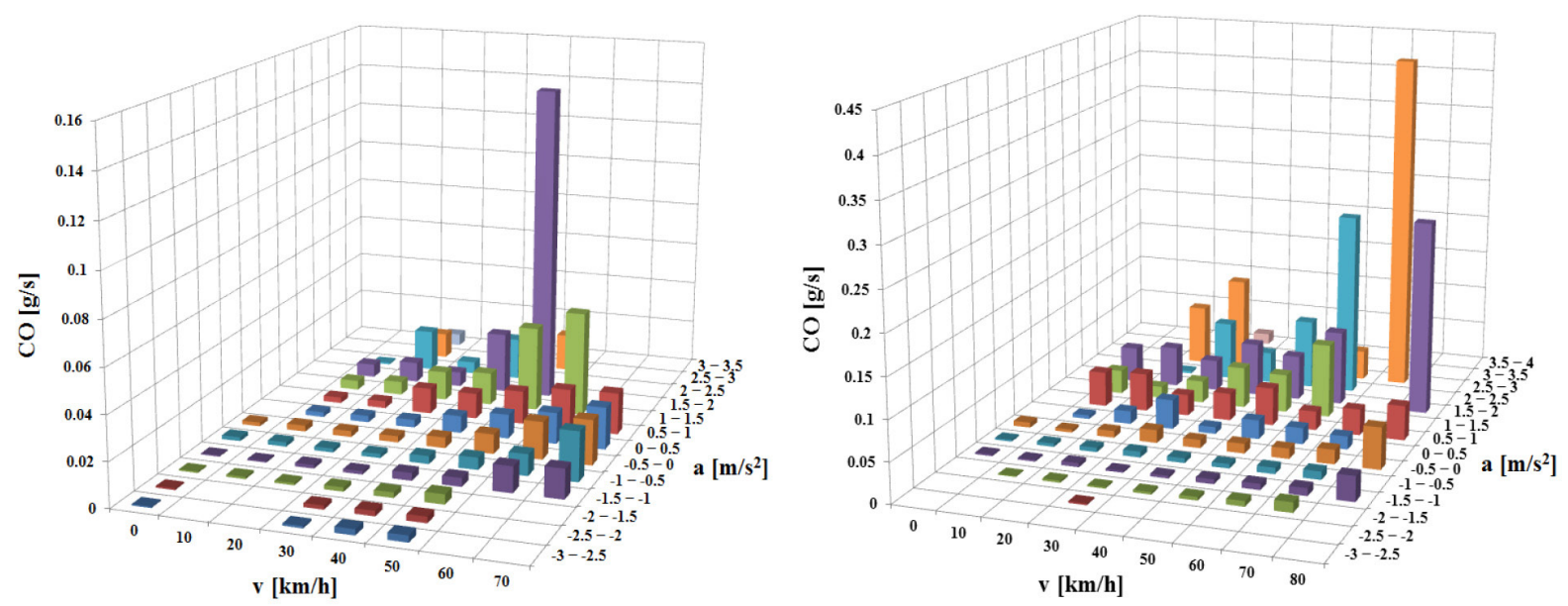

Fig. 13. CO exhaust emission in speed and acceleration intervals a) motorcycle with engine displacement of $125 \mathrm{~cm}^{3}$ b) motorcycle with engine displacement of $900 \mathrm{~cm}^{3}$ 
and $\left(3-3.5 \mathrm{~m} / \mathrm{s}^{2}\right)$ as well as $(70-80 \mathrm{~km} / \mathrm{h})$ and $\left(1.2-2 \mathrm{~m} / \mathrm{s}^{2}\right)$. For high vehicle speed, the injected fuel dose did not mix thoroughly, which led to incomplete combustion. The distribution of hydrocarbon emission values for the first drive is more uniform compared to the distribution obtained during the second drive of the more motorcycle with the more powerful engine. The mean values obtained in the tests were $0.0013 \mathrm{~g} / \mathrm{s}$ and $0.005 \mathrm{~g} / \mathrm{s}$, respectively.

The last analyzed toxic exhaust compound was $\mathrm{NO}_{\mathrm{x}}$. The highest values were found in the interval of high vehicle accelerations (Fig. 14). The maximum emission value for the first vehicle was recorded for vehicle speeds in the interval $(30-40 \mathrm{~km} / \mathrm{h})$ and accelerations in the interval $\left(2-2.5 \mathrm{~m} / \mathrm{s}^{2}\right)$, and reached the value of $0.0039 \mathrm{~g} / \mathrm{s}$. The local maximum for the second test vehicle was $0.0043 \mathrm{~g} / \mathrm{s}$, and this value was recorded for vehicle speeds in the interval $(60-70 \mathrm{~km} / \mathrm{h})$ and accelerations in the interval $\left(2.5-3 \mathrm{~m} / \mathrm{s}^{2}\right)$. High acceleration of the vehicle generates a higher temperature in the engine cylinder, which directly promotes the formation of nitrogen oxides. The average $\mathrm{NO}_{\mathrm{x}}$ exhaust emission values for both test drives were $0.0052 \mathrm{~g} / \mathrm{s}$ and $0.00021 \mathrm{~g} / \mathrm{s}$ for motorcycles with a $125 \mathrm{~cm}^{3}$ and $900 \mathrm{~cm}^{3}$ displacement engines, respectively.

The road emission values of all the measured compounds restricted under the EURO 4 norm were compared to their respective limit values in the said standard. For the motorcycle with a larger engine displacement value, $133 \%$ and $116 \%$ exceedances of carbon monoxide and hydrocarbon emissions were recorded (Fig. 15). For the motorcycle with lower power, a 57\% exceedance was recorded for nitrogen oxides, which is associated with higher engine loads as a result of driving with lower maximum power.
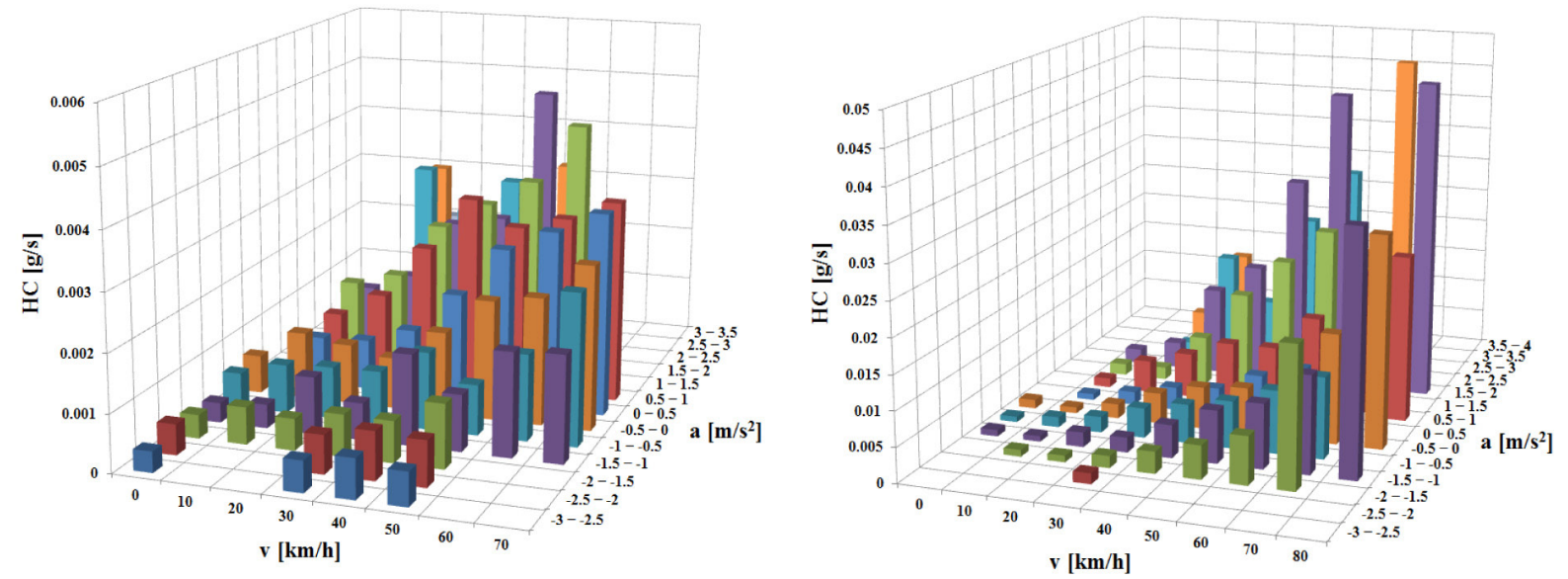

Fig. 14. HC exhaust emission in speed and acceleration intervals a) motorcycle with engine displacement of $125 \mathrm{~cm}^{3}$ b) motorcycle with engine displacement of $900 \mathrm{~cm}^{3}$
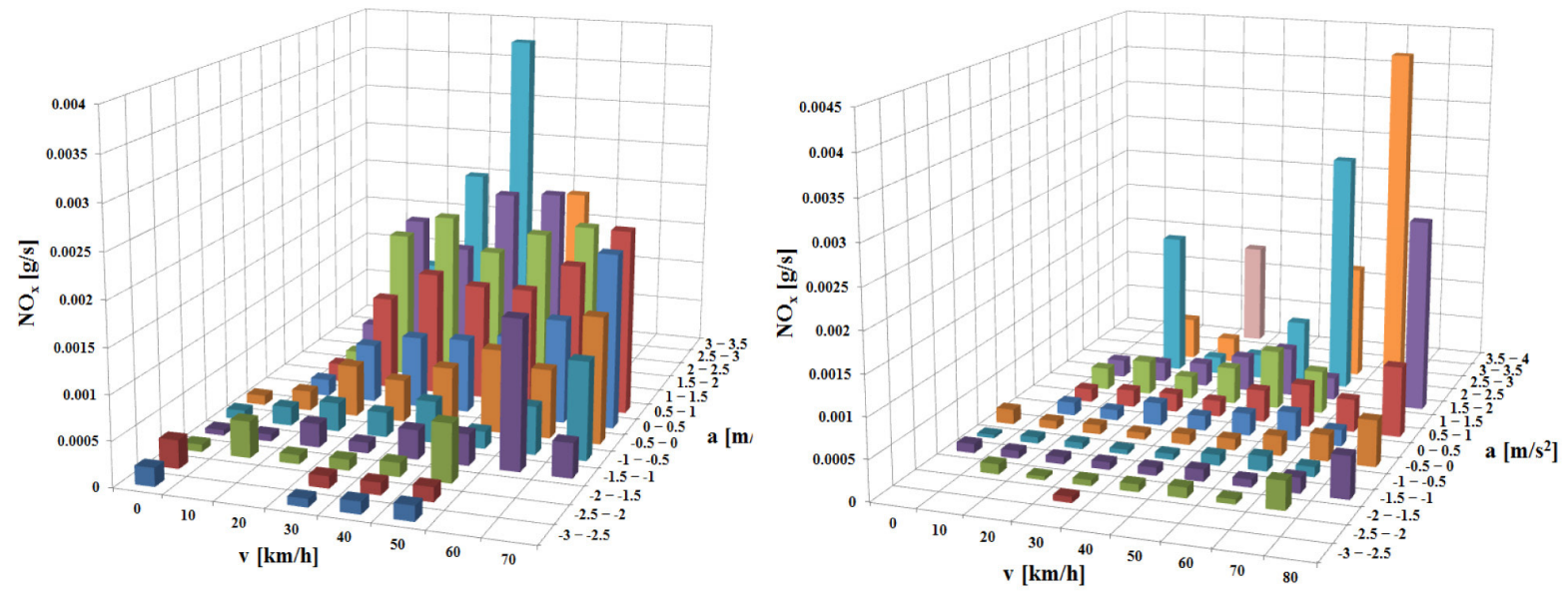

Fig. 15. $\mathrm{NO}_{\mathrm{x}}$ exhaust emission in speed and acceleration intervals a) motorcycle with engine displacement of $125 \mathrm{~cm}^{3}$ b) motorcycle with engine displacement of $900 \mathrm{~cm}^{3}$ 


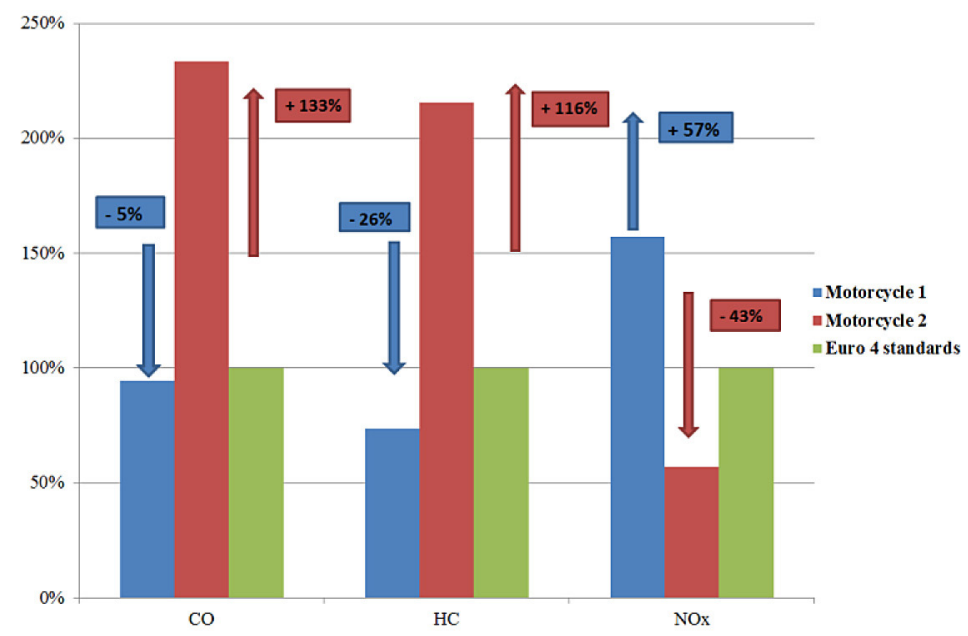

Figure 16. Comparison of the obtained road emission results with the EURO 4 norm

This phenomenon is the result of more diverse operating conditions of the engine under operating conditions than is the case with the type-approval test limited in terms of engine load range. Performing tests under actual operating conditions means that the engine load characteristics constituted a realistic representation of transient engine states, not just a dynamometer engine load curve, as it was in the case of a laboratory test. The results prove the need to introduce the RDE methodology into exhaust emissions testing for two-wheeled vehicles and tightening the regulations, as their emission drastically deviates from the accepted standards.

\section{CONCLUSIONS}

The emission norms for two-wheelers are updated less frequently than their car counterparts. Thus, any changes that take place are more severe for their manufacturers as well as end users, and each of them requires the use of new, increasingly advanced technologies, which includes both modern mechanical and electronic solutions. They also force the implementation of new emission tests, and the existing ones are characterized by increasingly higher accuracy and similarity to the actual operating conditions of vehicles. However, the results of the test carried out on two twowheeled units with engines of different maximum power and displacement values showed that the changes in regulations are indeed necessary. The exhaust emission values obtained under actual conditions differ from the limit values. For each of the vehicles, the emission limits were exceeded for a minimum of one toxic exhaust compound.
The emergence of new research opportunities in the form of small-scale and lightweight measuring equipment facilitates testing two-wheeled vehicles under actual operating conditions. Such conditions give the most reliable and complete results on the operational parameters and the intensity of exhaust emissions from motor vehicles. These studies are intended to be used by the authors to propose an RDE testing methodology for two-wheeled vehicles in further work. The consequences of research and the methodology created (reduction of limits or design solutions to reduce the exhaust emission values) will directly affect both comfort and human health, especially in the case of residents of large urban agglomerations who are especially exposed to air pollution.

\section{REFERENCES}

1. Commission Directive 2005/21/EC of 7 March 2005 adapting to technical progress Council Directive $72 / 306 /$ EEC on the approximation of the laws of the Member States relating to the measures to be taken against the emission of pollutants from diesel engines for use in vehicles, Official Journal of the European Union, 2005.

2. Directive 2007/46/EC of the European Parliament and of the Council of 5 September 2007 establishing a framework for the approval of motor vehicles and their trailers, and of systems, components and separate technical units intended for such vehicles, Official Journal of the European Union, 2007.

3. Fuć, P., Lijewski P., Bajerlein, M., Molik, P., 2004. Analiza wybranych aspektów indykowania silników w warunkach rzeczywistej eksploatacji, Czasopismo Logistyka 4.

4. Giechaskiel, B., Zardini, A., Martini, G., 2015. 
Particle Emission Measurement from L-category Vehicles, SAE Technical Paper 2015-24-2512.

5. Hiesmayr, J., Kirchberger, R., Schmidt, S., Zinner, C., Filips, P., Hausberger, S., Wanker, R., Friedl, H., 2017. Results, assessment and legislative relevance of RDE and fuel consumption measurements of two-wheeler-applications. SAE Technical Paper 2017-32-0042.

6. Khanh Nguyen, D., Han Nguyen, T., Vinh Nguyen, D., 2018. Performance enhancement and emission reduction of used motorcycles using flexible fuel technology. Journal of the Energy Institute 91, 145-152.

7. Kumar, R, Durai, B.K., Saleh, W., Boswell, C., 2011. Comparison and evaluation of emissions for different driving cycles of motorcycles: A note. Transportation Research Part D: Transport and Environment $16,61-64$.

8. Merkisz, J., Mizera, J., Bajerlein, M., Rymaniak, Ł., Maj, P., 2014. The influence of Laser Treatment and the a Application of Reduced Pressure Force Piston Rings on the Engine Exhaust Emissions under the
Conditions of Engines Lubrications with Different Engine Oils. Applied Mechanics and Materials 518, 102-107.

9. Merkisz, J., Pielecha, J., Fuć, P., Lijewski, P., 2012. The analysis of the PEMS measurement of the exhaust emissions from city buses using different research procedures. IEEE Vehicle Power and Propulsion Conference VPPC, 903-907.

10. Pielecha, J., 2017. Badanie emisji zanieczyszczeń silników spalinowych. Wydawnictwo Politechniki Poznańskiej.

11. Tong, H.Y., Hung, W.T., Cheung, C.S., 2000. Onroad motor vehicle emissions and fuel consumption in urban driving conditions. Journal of Air Waste Management Association 50, 543-554.

12. Worldwide Emissions Standards, Passenger Cars and Light Duty. Delphi Innovation for the Real World 2016/2017.

13. www.asphaltandrubber.com

14. www.caremissiontestingfacts.eu

15. www.globalmrv.com

16. www.gpsvisualizer.com 